\title{
Quality Assessment of Nile Tilapia and Grey Mullet Fish Collected from Different Local Markets in Alexandria City, Egypt
}

\author{
Saadia, M. H. Mohamed, Abdel-Nabey, A. A., Khalil, M. K. M. \& Abo Samaha, O. R. \\ Food Science and Technology Dept., Fac. of Agric., Alexandria University, El-Shatby, 21454, \\ Alexandria, Egypt
}

Received: 14 March, 2018

Revised: 7 May, 2018

Accepted: 13 May, 2018

\begin{abstract}
This study was conducted to determine quality parameters of Nile tilapia (Oreochromis niloticus) and grey mullet (Mugil cephalus) which were collected from different local markets in Alexandria city, Egypt during 2015. According to the overall sensory scores, the Nile tilapia and mullet samples collected from the different local markets could be classified into three categories of quality grade as follows: High quality grade (score between 8 to 10), acceptable grade (score between 5 to 7.9 ) and unacceptable grade (less than 5).

The TVB-N values in the different samples were below the maximum value of $30 \mathrm{mg} \mathrm{N} / 100 \mathrm{~g}$ flesh (upper limit according to E. O. S. Q. C., 2005, ES: 3494). The TMA-N value of Nile tilapia and grey mullet collected from the different markets were within the recommended standard limits for acceptability.

The $\mathrm{pH}$ values of Nile tilapia varied from 7.01 to 7.38. The data obtained showed significant differences $(P<$ 0.05 ) among the samples. Further, Hanuvil market samples had the highest value of $\mathrm{pH}$, while samples collected from El Wardian market had the lowest value of $\mathrm{pH}$, with no significant differences between El Wardian, Alqsy and Bab Omar Pasha market samples. It was found that the $\mathrm{pH}$ values of grey mullet samples ranged from 6.74 to 7.18 . Hanuvil samples followed by El Amreya samples were recorded to have the highest value of $\mathrm{pH}$ with no significant difference between them. On the other hand, Bakkous samples followed by Zananiri samples showed the lowest value of $\mathrm{pH}$ with no significant difference between them.

The results indicated that the psychrophilic bacterial count of Nile tilapia and grey mullet collected from different markets were higher than mesophilic bacterial count. All Nile tilapia and grey mullet samples had high quality considering that the microbiological upper limit for fresh fish proposed by E. O. S. Q. C. (2005, ES: 3494) not exceed $10^{6} \mathrm{CFU} /$ flesh.
\end{abstract}

Key words: Nile tilapia, grey mullet, quality, sensory evaluation, bacteriological evaluation, TNB-N, TMA, pH.

\section{INTRODUCTION}

Nowadays, there is an increasing demand on fish which act as an important source of food around the world (Silva et al., 2011). The share of fisheries production used for direct human consumption increased from about $70 \%$ in the $1980 \mathrm{~s}$ to more than $85 \%$ in 2012 (FAO, 2014).

Egypt has one of the world's largest aquaculture sectors which makes a significant contribution to income, employment creation and food security. Animal source foods provide important sources of energy, micro and macro nutrients, but are commonly associated with food borne diseases. Livestock and fish value chains support the livelihoods of millions of rural and urban poor, for whom they can act as pathways out of poverty (ILRI, 2011).
A recent value chain analysis of the industry revealed that the farmed fish value chain in Egypt is mainly based on the production of Tilapia with Mullet; the first and second most important species on private fish farms. Other species of fish such as carp and catfish are farmed in small quantities (Eltholth et al., 2015).

Tilapia and Mullets are the most important fish species for mono and polyculture in Egypt. Nile tilapia (Oreochromis niloticus) constitutes about $70 \%$ of the Nile and lakes catch. They are important for their palatability, high nutritive value, reasonable price, high growth rate, reproduction and tolerance to adverse water quality (Balarian, $1979 \&$ Ishak, 1980).

Fish is one of the most highly perishable food products. During handling and storage quality deterioration of fresh fish rapidly occurs and limits the 
shelf life of the product. Most of the methods that have been used to estimate the quality of fresh fish measure or evaluate parameters that change, disappear or formed during deterioration of fish. These methods may be divided into several groups such as bacteriological and chemical methods (Huss, 1995).

Methods for evaluating freshness and quality of different marine species are based on measurements of post mortem changes associated with sensory, chemical, physical changes and bacteriological growth (Ocaño-Higuera et al., 2011).

There is little information regarding the quality assessment of Nile tilapia and grey mullet from different local markets in Egypt. Therefore, the present study was undertaken to evaluate quality and freshness of Nile tilapia and grey mullet using sensorial, chemical and bacteriological attributes.

\section{MATERIALS AND METHODS}

\section{Materials}

A total of 15 different samples of fish (Oreochromis niloticus \& Mugil cephalus) were collected from different local markets in Alexandria city, Egypt during 2015 (Table 1).

The edible portion of the meat from each sample was removed, homogenized using blender (Braun type: 4262).

Table 1: Local markets in Alexandria city

\begin{tabular}{ll}
\hline \multicolumn{1}{c}{ The region (district) } & \multicolumn{1}{c}{ Market name } \\
\hline Montazah district & $\begin{array}{l}\text { El Maamoura market } \\
\text { Asafra market } \\
\text { Derbala market }\end{array}$ \\
& Bakkous market \\
East Alexandria district & Zananiri market \\
& Alqsy market \\
The center of Alexandria & Shedia market \\
district & Gheat Elsaaeidy market \\
& Zine Elabidine market \\
West Alexandria district & El Wardian market \\
& Bab Omar pasha market \\
& El Maydan market \\
El Amreya district & Hanuvil market \\
& Dekhela market \\
& El Amreya market \\
\hline
\end{tabular}

\section{Methods}

\section{Sensory evaluation}

Sensory evaluation of raw tilapia and mullet was performed by ten trained panelists chosen from the staff members of the Department of Food Science and Technology, Faculty of Agriculture, Alexandria University. The organoleptic assessment of raw tilapia and mullet were made according to the scale described by Barile et al. (1985). This scale ranged from zero (extremely unacceptable) to 10 (highly acceptable) for the following characteristics: acceptability, eye, pupil gills, body surface (appearance), odour, texture, flesh condition, viscera and belly wall.

Sensory evaluation of steamed cooked tilapia and mullet samples was applied after steaming in lidded aluminum pan for $10 \mathrm{~min}$. The panelists were asked to score the organoleptic properties of the sample by giving scores ranged between 0 to 10 as described by Barile et al. (1985).

\section{Total volatile basic-nitrogen (TVB -N)}

Fish extracts for determination of TVB-N were prepared by homogenizing $10 \mathrm{~g}$ fish sample with 90 $\mathrm{ml} 7.5 \%(\mathrm{w} / \mathrm{v})$ aqueous trichloroacetic acid (TCA) solution using a laboratory homogenizer for $1 \mathrm{~min}$ at high speed. The homogenate was centrifuged at $1409 \times \mathrm{g}$ for $5 \mathrm{~min}$ and the supernatant was filtered through Whatman No. 1 filter paper. The TVB -N were measured by steam- distillation of the TCA -fish extract, using the method of Malle \& Tao (1987). Twenty-five $\mathrm{ml}$ of the filtrate were added to a Kjeldahl- type distillation tube, followed by $5 \mathrm{ml}$ of $10 \%(\mathrm{w} / \mathrm{v})$ aqueous $\mathrm{NaOH}$ solution. Steam distillation was performed using a vertical steam distillation unit and the distillate was received into a beaker containing $15 \mathrm{ml}$ of $4 \%(\mathrm{w} / \mathrm{v})$ aqueous boric acid and $0.04 \mathrm{ml}$ of methyl red and bromocresol green indicator solution up to a final volume of $50 \mathrm{ml}$. The titration was allowed to run against aqueous $0.05 \mathrm{M}$ sulphuric acid solution. The results were expressed as mg nitrogen per $100 \mathrm{~g}$ fish sample.

\section{Trimethylamine (TMA)}

Trimethylamine (TMA) was determined in one run with the TVB-N according to the method described by AMC (1979). The nitrogen content of these volatile bases which did not react with formaldehyde was calculated, as TMA. After the back titration of excess acid during the determination of TVB-N, aliquot of $1 \mathrm{ml}$ of $16 \%(\mathrm{w} / \mathrm{v})$ formaldehyde solution was added for every $10 \mathrm{ml}$ liquid in the titration flask in order to make amines other than TMA react with formaldehyde and the acid released was titrated with standard alkali. The results were expressed as mg nitrogen per $100 \mathrm{~g}$ fish sample. 


\section{pH value}

Five $\mathrm{g}$ of fish sample were homogenized in 50 $\mathrm{ml}$ distilled water at the ratio $1: 10(\mathrm{w} / \mathrm{v})$ using laboratory Warring blender and the $\mathrm{pH}$ was measured using a digital $\mathrm{pH}$ meter ( $\mathrm{pH}$ 211, Microprocessor $\mathrm{pH})$. The $\mathrm{pH}$ meter was calibrated using buffers of pH 4 and 7 (Goulas \& Kontominas, 2007).

\section{Bacteriological analysis}

Ten $\mathrm{g}$ of flesh were transferred into $90 \mathrm{ml} \mathrm{0.1 \%}$ peptone water. From this dilution, other decimal dilutions were prepared. Total psychrophilic and mesophilic bacterial count were determined by the pour plating technique, using plate count agar (PCA) and the plates were inverted and incubated in an incubator at $35^{\circ} \mathrm{C}$ for $48 \mathrm{hr}$ for mesophilic bacteria and at $7-10^{\circ} \mathrm{C}$ for 10 days for psychrophilic bacteria (Bahmani et al., 2011).

Finally, the number of colonies were counted and multiplied by dilution factor to calculate the total colonies forming units per g sample (Abelti, 2013).

\section{Statistical analysis}

Analysis of variance and correlations were carried out according to Gomez \& Gomez (1984) using SAS (Statistical Analysis System) ver.9.1, 2000 .

\section{RESULTS AND DISCUSSION}

\section{Nile tilapia collected from different markets}

\section{Sensory evaluation}

The data for sensory evaluation of raw and steamed Nile tilapia samples collected from different local markets in Alexandria city are presented in Tables ( $2 \& 3)$. The values were calculated as means of ten scoring evaluations.

The results indicated that the sensory evaluation scores of Nile tilapia samples collected from different local markets in Alexandria city varied significantly. Also, as shown from Tables (2 \& 3), the overall acceptability scores varied from 4.9 to 9.9 and from 5.3to 9.9 for raw and steamed samples, respectively.

The highest overall acceptability was detected in Shedia and Zananiri market samples, while the lowest overall acceptability score was recorded in samples collected from Hanuvil and Derbala markets for both raw and steamed samples. This may be attributed to the higher bacterial load of samples collected from Hanuvil and Derbala markets compared to those obtained from the other markets (Table 4).

The overall sensory scores less than 5 points mean that Nile tilapia samples are organoleptically rejected (Barile et al., 1985). According to the overall sensory scores (Tables $2 \& 3$ ), the samples collected from different local markets could be classified into three categories of quality grade as follows: (1) high quality grade (samples collected from Shedia, Zananiri, Zine Elabidine, Alqsy, El Wardian and Bab Omar pasha markets) (2) acceptable grade (samples collected from Gheat Elsaaeidy, Bakkous, El Maydan, El Maamoura, Asafra , Derbala ,Dekhela and El Amreya markets), (3) unacceptable grade (Hanuvil market samples).

\section{The TVB-N of tilapia}

The results in Table (4) show TVB-N of Nile tilapia collected from different local markets in Alexandria city. According to these data, it can be concluded that the TVB-N content of the market samples ranged from 10.21 to $26.77 \mathrm{mg} \mathrm{N} / 100 \mathrm{~g}$ flesh. It was found that the TVB-N value varied significantly $(P<0.05)$ between different market samples. Meanwhile, Hanuvil market samples had the higher amount of TVB-N, while samples collected from Bab Omar pasha market had the lower level of TVB-N with no significant differences observed between El Wardian, Alqsy and Bab Omar pasha market samples.

Differences in levels of TVB-N may be due the activity of proteolytic enzymes by bacterial action which produced some volatile compounds under low temperature (Nunes et al., 1992, AbouTaleb \& Ibrahim, 2002). Also, Mazorra-Manzano et al. (2000) reported that this increment may be due to ammonia production in the muscle during storage from bacterial catabolism of nitrogen, due to the fact that TVB-N levels still rise as a result of the $\mathrm{NH}_{3}$ formation and other volatile amines.

It was clear that all concentrations of TVB-N are lower than the safety limits suggested by CEC (1995), Connell (1995), Huss (1995), Gökodlu et al. (1998), Lopez-Caballero et al. (2000), E.O.S.Q.C. (2005), Muhammet \& Sevim (2007) and Liu et al. (2010), which set TVB-N values of 30-35 $\mathrm{mg} \mathrm{N} / 100 \mathrm{~g}$ flesh regarded as the limit of acceptability. 


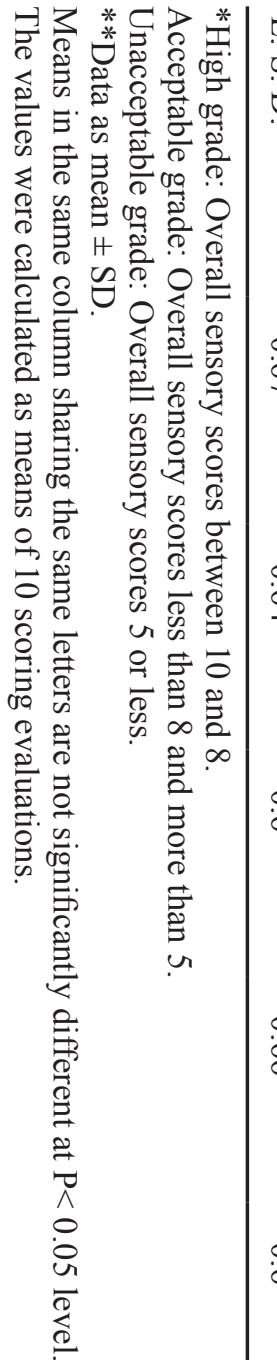

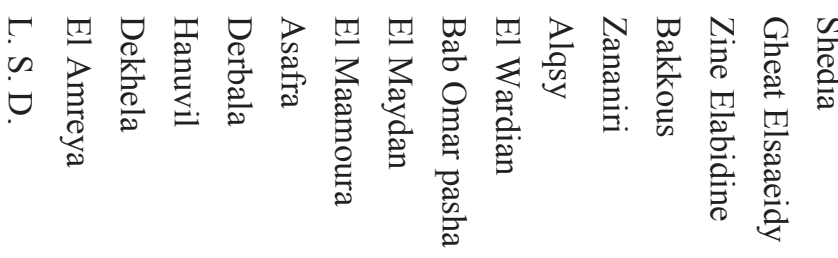

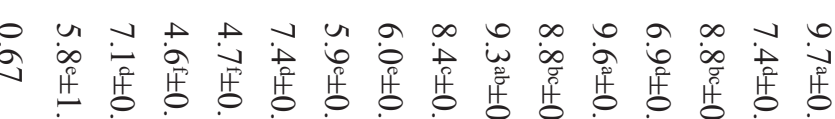

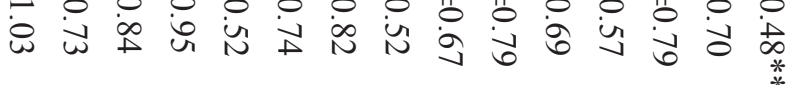

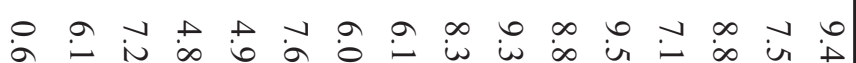

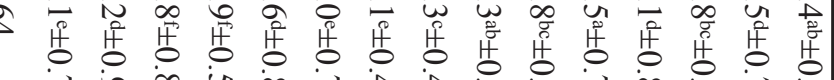
$\vec{\perp}$ iᄋ

- $\cdots+u v$ un $\infty$ u

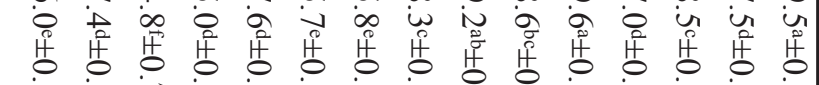

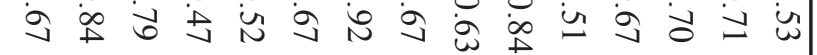

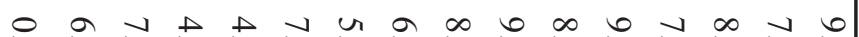

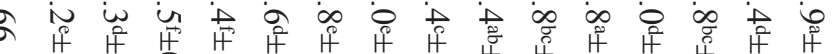

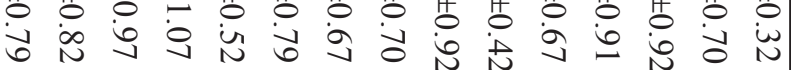

0 b

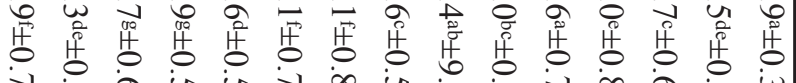

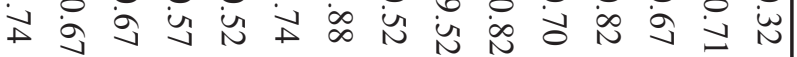

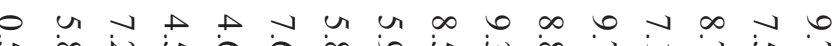

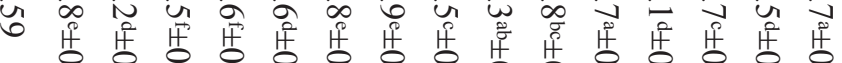

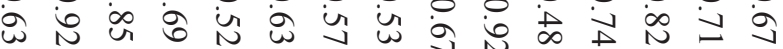

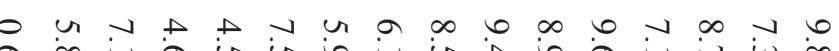

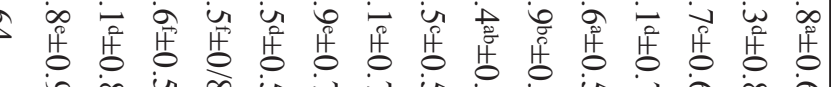

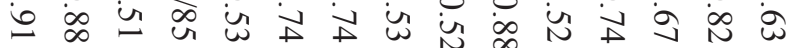

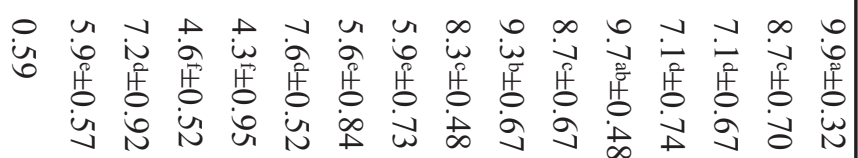

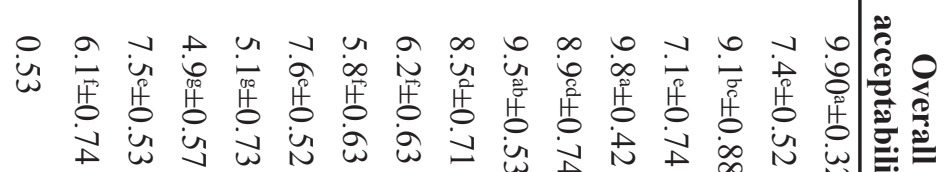

: 
Table 3: Sensory evaluation"of steamed Nile tilapia samples

\begin{tabular}{|c|c|c|c|c|}
\hline \multirow[t]{2}{*}{ Market name } & \multicolumn{4}{|c|}{ Sensory quality parameters } \\
\hline & Odour & Taste & Texture & Overall acceptability \\
\hline Shedia & $9.8 \mathrm{a} \pm 0.42^{* *}$ & $9.6^{\mathrm{a}} \pm 0.70$ & $9.8^{\mathrm{a}} \pm 0.43$ & $9.9 \mathrm{a} \pm 0.32$ \\
\hline Gheat Elsaaeidy & $7.8 \mathrm{e} \pm 0.63$ & $7.6 \mathrm{e} \pm 0.52$ & $8.0^{\mathrm{de}} \pm 0.47$ & $8.2^{\mathrm{de}} \pm 0.42$ \\
\hline Zine Elabidine & $8.9 b c \pm 0.74$ & $8.6^{\mathrm{b}} \pm 0.69$ & $8.8^{\mathrm{b}} \pm 0.79$ & $9.1 \mathrm{bc} \pm 0.74$ \\
\hline Bakkous & $7.7 \mathrm{e} \pm 0.95$ & $7.7 \mathrm{e} \pm 0.67$ & $7.8 \mathrm{e} \pm 0.79$ & $7.9^{\mathrm{e}} \pm 0.74$ \\
\hline Zananiri & $9.7 \mathrm{a} \pm 0.48$ & $9.3^{\mathrm{a}} \pm 0.82$ & $9.7 \mathrm{a} \pm 0.48$ & $9.8 \mathrm{a} \pm 0.42$ \\
\hline Alqsy & $8.6^{\mathrm{cd}} \pm 0.70$ & $8.4^{b c} \pm 0.69$ & $8.6^{\mathrm{bc}} \pm 0.69$ & $8.7^{\mathrm{cd}} \pm 0.82$ \\
\hline El Wardian & $9.5^{\mathrm{ab}} \pm 0.53$ & $9.2^{\mathrm{a}} \pm 0.79$ & $9.4^{\mathrm{a}} \pm 0.51$ & $9.6^{\mathrm{ab}} \pm 0.52$ \\
\hline Bab Omar pasha & $8.6^{\mathrm{cd}} \pm 0.52$ & $8.3^{\mathrm{bcd}} \pm 0.48$ & $8.5^{\mathrm{bcd}} \pm 0.52$ & $8.9^{c} \pm 0.93$ \\
\hline El Maydan & $6.3 \mathrm{f} \pm 0.67$ & $6.0 \mathrm{f} \pm 0.47$ & $6.1^{\mathrm{f}} \pm 0.74$ & $6.1^{\mathrm{f}} \pm 0.74$ \\
\hline El Maamoura & $6.4 \mathrm{f} \pm 0.84$ & $6.0 \mathrm{f} \pm 0.67$ & $6.0 \mathrm{f} \pm 0.66$ & $6.1^{\mathrm{f}} \pm 0.73$ \\
\hline Asafra & $8.1^{\mathrm{de}} \pm 0.57$ & $7.8^{\mathrm{de}} \pm 0.78$ & $8.3^{\text {bcde }} \pm 0.67$ & $8.0 \mathrm{e} \pm 0.47$ \\
\hline Derbala & $5.0 \mathrm{~g} \pm 0.94$ & $5.2^{\mathrm{g}} \pm 0.63$ & $5.2^{\mathrm{g}} \pm 0.78$ & $5.3^{\mathrm{g}} \pm 0.48$ \\
\hline Hanuvil & $4.9^{\mathrm{g}} \pm 0.87$ & $4.8^{\mathrm{g}} \pm 0.79$ & $5.0 \mathrm{~g} \pm 0.82$ & $5.4 \mathrm{~g} \pm 0.52$ \\
\hline Dekhela & $8.0^{\mathrm{de}} \pm 0.47$ & $8.0^{\text {cde }} \pm 0.67$ & $8.1^{\text {bcde }} \pm 0.32$ & $8.2^{\mathrm{de}} \pm 0.42$ \\
\hline El Amreya & $6.2^{\mathrm{f}} \pm 0.63$ & $6.0^{\mathrm{f}} \pm 0.47$ & $6.2^{\mathrm{f}} \pm 0.42$ & $6.4^{\mathrm{f}} \pm 0.52$ \\
\hline L. S. D. & 0.6 & 0.58 & 0.55 & 0.53 \\
\hline
\end{tabular}

${ }^{*}$ High grade: Overall sensory scores between 10 and 8 .

Acceptable grade: Overall sensory scores less than 8 and more than 5.

Unacceptable grade: Overall sensory scores 5 or less.

${ }^{* *}$ Data as mean $\pm \mathrm{SD}$.

Means in the same column sharing the same letters are not significantly different at $P<0.05$ level.

\section{The TMA-N of tilapia}

The results in Table (4) reveal that the TMA-N of Nile tilapia collected from different local markets in Alexandria city varied between 5.13 to 8.21 $\mathrm{mg} \mathrm{N} / 100 \mathrm{~g}$ flesh. TVB-N value varied significantly $(P<0.05)$ between different market samples.

Hanuvil sample had the highest value of TMAN. On the other hand, Bab Omar pasha samples followed by El Wardian samples showed the lowest value of TMA-N, with no significant difference between them.

From the results obtained in the present study, it can be concluded that a correlation was observed between the results of TMA-N and bacterial load. In accordance with the results obtained here, El Marrakchi et al. (1990) mentioned that The TMA production in fish tissue could be used as an indicator of bacterial activity and it is an accepted deterioration measure.

The TMA-N value of Nile tilapia collected from the different local markets in Alexandria city was below rejection limit of TMA-N proposed by Huss (1978), AOAC (1984), FAO (1986), \& Ruiz-
Capillas \& Moral (2001) which is within the range of recommended limit of rejection of 10 to $18 \mathrm{mg}$ N/100g. Also, TMA-N value was blew rejection limit of many fish species which is usually from 5-10 mg TMA-N /100g muscles as reported by Fathia et al. (2013).

\section{The $\mathbf{p H}$ values of tilapia}

The $\mathrm{pH}$ values of Nile tilapia collected from different local markets in Alexandria city are summarized in Table (4). The data obtained show significant differences $(P<0.05)$ among the samples collected from the different markets.

The $\mathrm{pH}$ values of Nile tilapia varied from 7.01 to 7.38. Further, Hanuvil market samples had the highest value of $\mathrm{pH}$. On the other hand, El Wardian, Alqsy and Bab Omar Pasha market samples exhibited the lowest value of $\mathrm{pH}$ with no significant difference between them. This result is consistent with the results of TVB-N, TMA-N and microbial load.

The results in the present study showed that $\mathrm{pH}$ value was above value of 7 . The increment in $\mathrm{pH}$ may also be due to an increase in total volatile bases 
from the decomposition of nitrogenous compounds by endogenous or microbial enzymes and this corroborates with the increase in TVB- N. These results agreed with those previously reported (Khallaf, 1986, Galli et al., 1993, Kyrana et al., 1997, Pacheco-Aguilar et al.,2003, Daramola et al., 2007, Erkan \& Ozden, 2008, Okeyo et al., 2009, Salaudeen et al., 2010, Goliat et al., 2016 Moawad et al., 2017). Such an increment in the $\mathrm{pH}$ indicates the bacterial growth, loss of quality and possible spoilage (Sallam et al., 2007, Moawad et al., 2017).

\section{Bacterial count of tilapia}

Bacterial count of Nile tilapia collected from different local markets in Alexandria city are given in Table (4). The data obtained showed significant differences $(P<0.05)$ among the samples collected from the different markets for both mesophilic and psychrophilic bacterial count.

The mesophilic bacterial count ranged from $8.47 \times 10^{2} \mathrm{CFU} / \mathrm{g}$ flesh to $9.83 \times 10^{4} \mathrm{CFU} / \mathrm{g}$ flesh for Zine Elabidine and Hanuvil market samples, respectively. On the other hand, the psychrophilic bacterial count ranged from $9.73 \times 10^{2} \mathrm{CFU} / \mathrm{g}$ flesh to $5.17 \times 10^{5} \mathrm{CFU} / \mathrm{g}$ flesh for El Wardian and Hanuvil market samples, respectively.

The present study indicate that the psychrophilic bacterial counts of Nile tilapia collected from the different markets were higher than mesophilic bacterial count.

All Nile tilapia samples had high quality considering that the microbiological upper limit for fresh fish proposed by ICMSF (1986), IFST (1999) \& E. O. S. Q. C. (2005) not exceed $10^{6} \mathrm{CFU} / \mathrm{g}$ flesh.

\section{Grey mullet collected from different markets}

\section{Sensory evaluation}

Sensory evaluation of raw and steamed grey mullet collected from different local markets in Alexandria city are shown in Tables (5 and 6). The results show significant differences among the samples collected from the different markets. The overall acceptability ranged from 4.6 to 9.3 and from 4.8 to 9.1 for raw and steamed grey mullet collected from the different markets, respectively.

Samples taken from Gheat Elsaaeidy and Bakkous markets possessed higher overall acceptability scores for both raw and steamed samples. However, the lower overall acceptability was recorded in Hanuvil samples.
The overall sensory scores less than 5 points mean that grey mullet samples are organoleptically rejected (Barile et al., 1985). According to the overall sensory scores (Tables 5 and 6), the samples collected from Shedia, Zine Elabidine, Alqsy, Gheat Elsaaeidy and Bakkous, markets had a higher quality grade, as well as acceptable grade was observed in samples collected from El Maydan, El Maamoura, Asafra, Zananiri, Derbala, Dekhela, El Wardian, Bab Omar pasha and El Amreya markets). On the other hand, unacceptable grade was noted in Hanuvil market samples.

\section{TVB-N of grey mullet}

Table (7) shows the values of TVB-N of grey mullet collected from different local markets in Alexandria city. The results indicated that the TVB-N content of the market samples ranged from 7.79 to $24.52 \mathrm{mg} \mathrm{N} / 100 \mathrm{~g}$ flesh. It was found that the TVB$\mathrm{N}$ value varied significantly $(P<0.05)$ between the different market samples. A significantly $(P<0.05)$ higher value of $24.52 \mathrm{mg} \mathrm{N} / 100 \mathrm{~g}$ flesh was detected in TVB-N for Hanuvil market samples comparing with the other different samples. These increment may be attributed to the breakdown of nitrogenous substances as a result of microbial activity and any autolytic enzymes found naturally in fish tissues (El-Shamery, 2010). On the other hand, Zananiri market samples showed the lowest TVB-N level. No significant difference was noted between Zananiri, Bakkous and Zine Elabidine samples with respect to their content of TVB-N.

From the results obtained in the present study, it can be shown a correlation between the results of TVB-N, TMA-N, pH and bacterial load. These results agreed with those reported by Fernandez et al. (2009) \& Jinadasa (2014). They found that the increment in the amount of TVB-N is parallel with the increase in TMA during spoilage. Further, these results are in agreement with the results recorded by Yasmin et al. (2001), Özyurt et al. (2009), Liu et al. (2010). They reported that significant correlation coefficient was observed between TVB-N changes and changes in mesophilic aerobic bacterial count.

All TVB-N values in the different samples, are below the maximum value of $30 \mathrm{mg} \mathrm{N} / 100 \mathrm{~g}$ flesh specified by CEC (1995), Connell (1995), Huss (1995), Gökodlu et al. (1998), Lopez-Caballero et al. (2000), E. O. S. Q. C (2005), Muhammet \& Sevim (2007) \& Liu et al. (2010), which set 


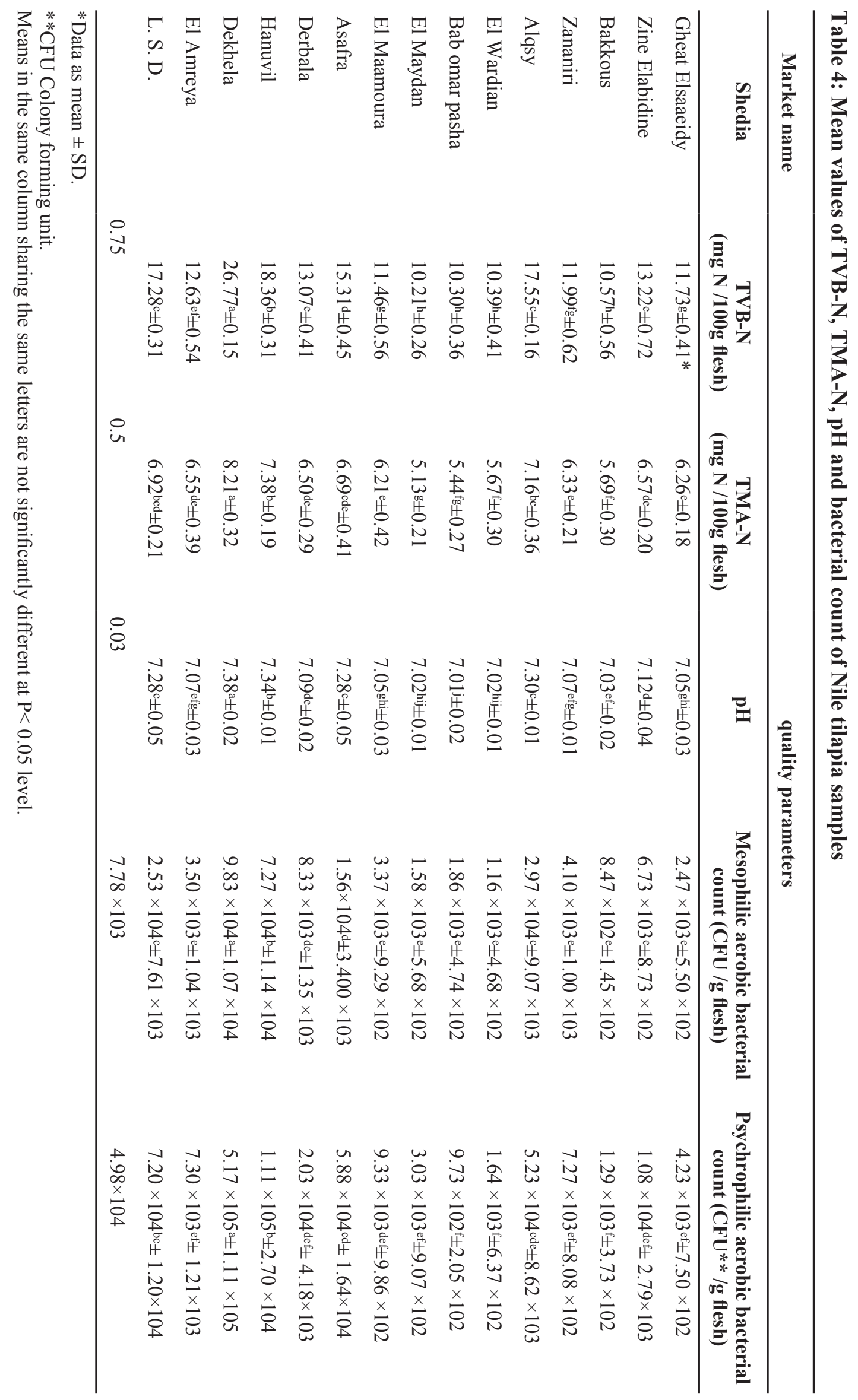




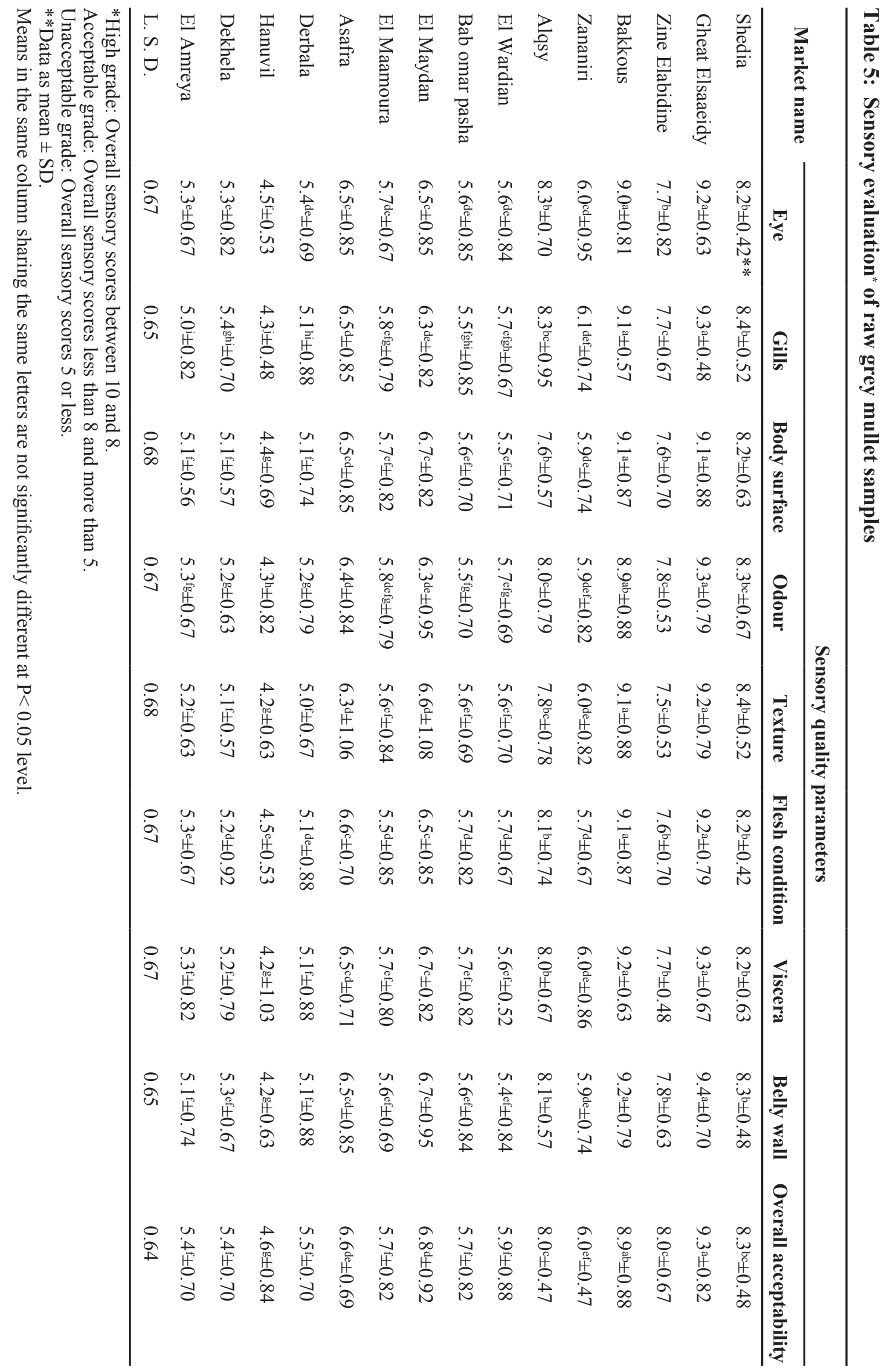


Table 6: Sensory evaluation*of steamed grey mullet samples

\begin{tabular}{|c|c|c|c|c|}
\hline \multirow{2}{*}{ Market name } & \multicolumn{4}{|c|}{ Sensory quality parameters } \\
\hline & Odour & Texture & Taste & Overall acceptability \\
\hline Shedia & $8.4^{b} \pm 0.52^{* *}$ & $8.1^{b c} \pm 0.74$ & $8.6^{c} \pm 0.52$ & $8.5^{\mathrm{ab}} \pm 0.71$ \\
\hline Gheat Elsaaeidy & $9.2^{\mathrm{a}} \pm 0.63$ & $9.0^{\mathrm{a}} \pm 0.94$ & $9.3^{\mathrm{a}} \pm 0.48$ & $9.1^{\mathrm{a}} \pm 0.88$ \\
\hline Zine Elabidine & $8.3^{\mathrm{b}} \pm 0.48$ & $7.9^{c} \pm 0.57$ & $8.2^{c} \pm 0.63$ & $8.2^{b} \pm 0.42$ \\
\hline Bakkous & $9.2^{\mathrm{a}} \pm 0.79$ & $8.7^{\mathrm{ab}} \pm 1.06$ & $9.2^{\mathrm{ab}} \pm 0.79$ & $9.1^{\mathrm{a}} \pm 0.74$ \\
\hline Zananiri & $6.2^{\mathrm{cd}} \pm 0.78$ & $5.9 \mathrm{de} \pm 0.73$ & $6.1^{\mathrm{de}} \pm 0.74$ & $6.4^{\mathrm{cde}} \pm 0.70$ \\
\hline Alqsy & $8.6^{\mathrm{ab}} \pm 0.67$ & $8.2^{\mathrm{bc}} \pm 0.63$ & $8.7^{b c} \pm 0.67$ & $8.5^{\mathrm{ab}} \pm 0.85$ \\
\hline El Wardian & $5.5 \mathrm{e} \pm 0.85$ & $5.3^{\mathrm{ef}} \pm 0.95$ & $5.6^{\mathrm{efg}} \pm 0.70$ & $5.8^{\mathrm{ef}} \pm 0.92$ \\
\hline Bab omar pasha & $5.5^{\mathrm{e}} \pm 0.85$ & $5.4^{\mathrm{ef}} \pm 0.97$ & $5.4^{\mathrm{fg}} \pm 0.69$ & $5.9^{\mathrm{def}} \pm 0.73$ \\
\hline El Maydan & $6.6^{c} \pm 0.84$ & $6.2 \mathrm{~d} \pm 0.63$ & $6.5^{\mathrm{d}} \pm 0.63$ & $6.7 \mathrm{c} \pm 0.82$ \\
\hline El Maamoura & $5.6^{\mathrm{de}} \pm 0.84$ & $5.5^{\mathrm{ef}} \pm 0.85$ & $5.6^{\mathrm{efg}} \pm 0.85$ & $5.8^{\mathrm{ef}} \pm 0.79$ \\
\hline Asafra & $6.2^{\mathrm{cd}} \pm 0.63$ & $5.7 \mathrm{de} \pm 0.67$ & $5.9 \mathrm{ef} \pm 0.94$ & $6.5^{\mathrm{cd}} \pm 0.53$ \\
\hline Derbala & $5.1 \mathrm{e} \pm 0.99$ & $5.0^{\mathrm{fg} \pm 0.94}$ & $5.5^{\mathrm{fg}} \pm 0.53$ & $5.6^{\mathrm{f}} \pm 0.70$ \\
\hline Hanuvil & $4.3^{\mathrm{f}} \pm 0.48$ & $4.5^{\mathrm{g}} \pm 0.53$ & $4.4^{\mathrm{h}} \pm 0.48$ & $4.8^{\mathrm{g}} \pm 0.52$ \\
\hline Dekhela & $5.4^{\mathrm{e}} \pm 0.52$ & $5.3^{\mathrm{ef}} \pm 0.48$ & $5.3^{\mathrm{g}} \pm 0.67$ & $5.6^{f} \pm 0.67$ \\
\hline El Amreya & $5.3 \mathrm{e} \pm 0.67$ & $5.4^{\mathrm{ef}} \pm 0.52$ & $5.5^{\mathrm{fg}} \pm 0.52$ & $5.7^{f} \pm 0.89$ \\
\hline L. S. D. & 0.62 & 0.68 & 0.59 & 0.64 \\
\hline
\end{tabular}

*High grade: Overall sensory scores between 10 and 8 .

Acceptable grade: Overall sensory scores less than 8 and more than 5 .

Unacceptable grade: Overall sensory scores 5 or less.

$* *$ Data as mean $\pm \mathrm{SD}$.

Means in the same column sharing the same letters are not significantly different at $\mathrm{P}<0.05$ level.

TVB-N values of 30-35 mg N/100g flesh regarded as the limit of acceptability.

\section{The TMA-N of grey mullet}

The data presented in Table (7) show the TMA$\mathrm{N}$ values of grey mullet collected from different local markets in Alexandria city. The results indicated that the TMA-N content of market samples ranged from 4.90 to $7.69 \mathrm{mg} \mathrm{N} / 100 \mathrm{~g}$ flesh. It was found that the TMA-N value varied significantly $(P<0.05)$ between the different market samples.

Hanuvil market samples followed by El Amreya samples showed the highest value of TMA-N, with no significant difference between them, while samples collected from Zananiri market followed by Bakkous had the lowest level of TMA-N with no significant differences observed between them.

The TMA-N values of grey mullet collected from the different local markets were within the recommended standard limits for acceptability proposed by Huss (1978), AOAC (1984), FAO (1986), Ruiz-Capillas \& Moral (2001) and Fathia et al. (2013).

\section{The pH values of grey mullet}

The data in Table (7) show the $\mathrm{pH}$ values of grey mullet collected from different local markets in Alexandria city. It was found that the $\mathrm{pH}$ value ranged from 6.74 to 7.13 .

Hanuvil samples followed by El Amreya samples were recorded to have the highest value of $\mathrm{pH}$ with no significant difference between them. On the other hand, Bakkous samples followed by Zananiri samples showed the lowest value of $\mathrm{pH}$ with no significant difference between them.

The post mortem acceptable $\mathrm{pH}$ is usually 6.87.0 (Zang \& Deng, 2012). After death of the fish, the glycogen present in the tissues gets oxidized to lactic acid and the creatine phosphate in the muscle breaks down releasing phosphoric acid (Huss, 


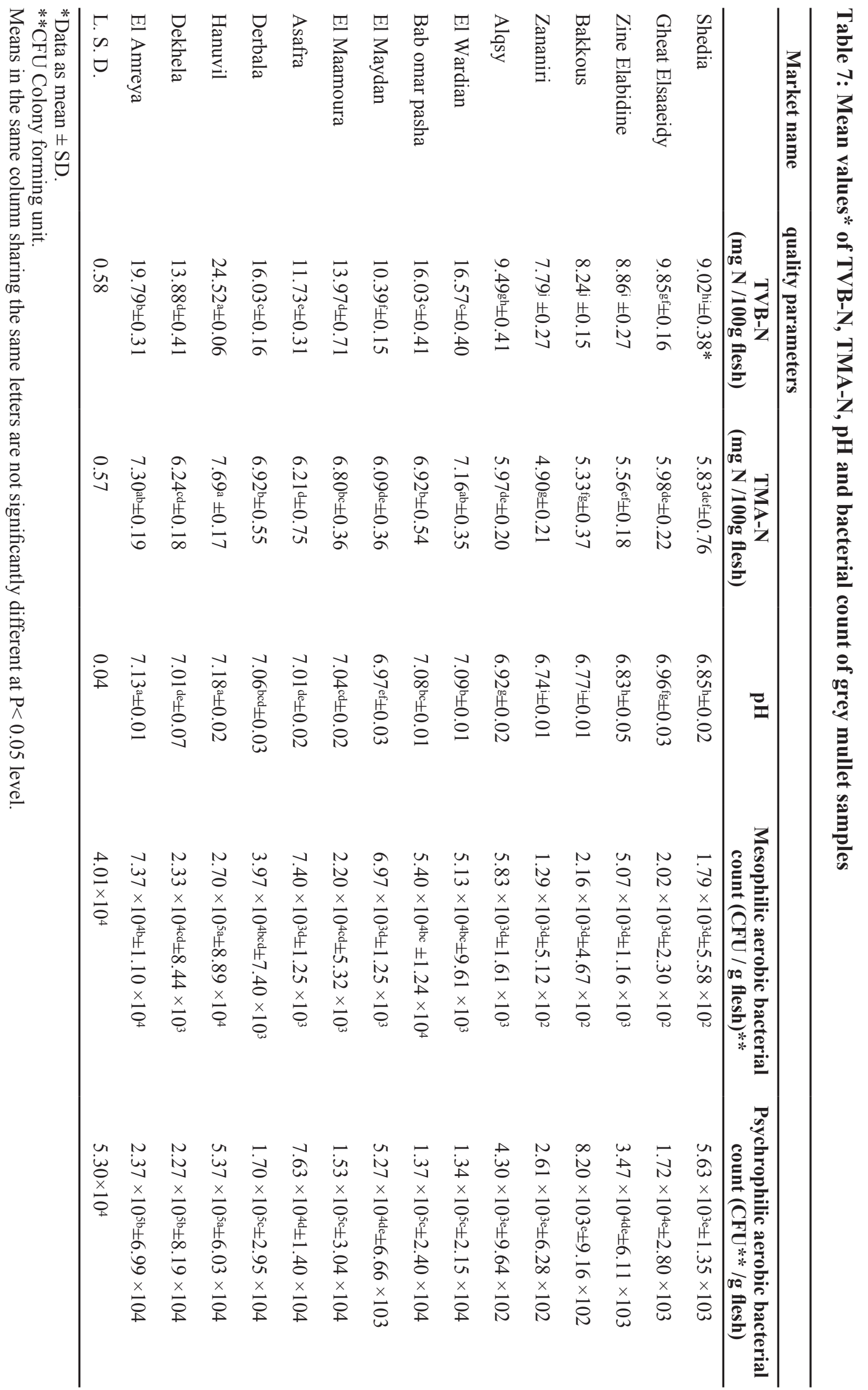


1995). A release of both lactic acid and phosphoric acid triggers rapid change in $\mathrm{pH}$ of tissue fluids (MANAGE, 2008).

The $\mathrm{pH}$ values of grey mullet collected from the different local markets were correlated well with the results of TVB-N, TMA-N and bacterial load.

\section{Bacterial count of grey mullet}

The data presented in Table (7) show the bacterial count of grey mullet collected from different local markets in Alexandria city. The results indicated that the significant differences $(P<0.05)$ were observed between the samples collected from the different markets for both mesophilic and psychrophilic bacterial count.

The mesophilic bacterial count ranged from $1.29 \times 10^{3} \mathrm{CFU} / \mathrm{g}$ flesh to $2.70 \times 10^{5} \mathrm{CFU} / \mathrm{g}$ flesh for Zananiri and Hanuvil market samples, respectively. The psychrophilic bacterial count ranged from $2.61 \times 10^{3} \mathrm{CFU} / \mathrm{g}$ flesh to $5.37 \times 10^{5} \mathrm{CFU} / \mathrm{g}$ flesh for Zananiri and Hanuvil market samples, respectively. Variation in the initial bacterial load could be ascribed to the microbial load of the waters in which they live (Huss, 1988). The eventual increase observed in mean total plate count could be due to multiplication of organisms favored at the storage condition (Ibrahim \& El -Sherif, 2008).

The present study indicated that the psychrophilic bacterial count of grey mullet collected from the different markets were higher than mesophilic bacterial count.

The levels of mesophilic and psychrophilic aerobic bacterial count of grey mullet collected from the different local markets, agreed greatly with the recommendations set by ICMSF (1986), IFST (1999) and E. O. S. Q. (2005) which claimed that the maximum bacterial limit for fresh fish never exceeds the $10^{6} \mathrm{CFU} / \mathrm{g}$ flesh.

\section{REFERENCES}

Abelti, A. L. 2013. Microbiological and chemical changes of Nile tilapia (Oreochromis niloticus L.) fillet during ice storage: effect of age and sex advance. Journal of Food Science and Technology, 5: $1260-1265$.

Abou-Taleb, M. \& Ibrahim, S. M. 2002. Relationship between freshness degree of Nile bolti fish and quality of its processed products. Annals of Agriculture Science, Moshtohor, 40: 1571-1582.
Analytical Methods Committee (AMC). 1979. Recommended general methods for the examination of fish and fish products. Analyst, 104: 434- 450.

Association of Official Methods of Analytical Chemists (AOAC). 1984. Official Methods of Analysis. (14 $\left.{ }^{\text {th }} \mathrm{Ed}\right)$, Arlington.

Bahmani, Z. A., Rezai, M. Hosseini, S. V., Regenstein, J. M., Böhme, K., Alishahi, A. \& Yadollahi, F. 2011. Chilled storage of golden gray mullet (Liza aurata). Food Science and Technology, 44: 1894-1900.

Balarian, J. D. 1979. Tilapia: A guide to their Biology and Culture in Africa. University of Sterling Press. pp: 1-79.

Barile, L. E., Milla, A. D., Reilly, A. \& Villadsen, A. 1985. Spoilage patterns of mackerel (Rastrielliger faughnimatsui)- mesophilic and psychrophilic spoilage. FAO Fisheries Research, 317: 146-154.

Commission of the European Community (CEC). 1995. Decision $95 / 149 / \mathrm{EC}$ of fixing the total volatile basic nitrogen (TVB-N) limit values for certain categories of fishery products and specifying the analysis methods to be used. Brussels: CEC.

Connell, J. J. 1995. Control of Fish Quality $.4^{\text {th }}$ ed. London: Fishing News Books Limited. pp: 240.

Daramola, J. A., Fasakin, E. A. \& Adeparusi, E. O. 2007. Changes in physiochemical and sensory characteristics of smoke-dried fish species stored at ambient temperature. African Journal of Food Agriculture Nutrition. and Development, 7: 1-16.

Egyptian Organization for Standardization and Quality Control (E.O.S.Q.C). 2005. Chilled Fish. ES: 3494: 1-12.

El Marrakchi, A., Bennour, M., Bouchriti, N., Hamama, A. \& Tagafait, H. 1990. Sensory, chemical, and microbiological assessments of Moroccan sardines (Sardina pilchardus) stored in ice. Journal of Food Protection, 53: 600- 605.

El-Shamery, G. 2010. Studies on contamination and quality of fresh fish meats during storage. Egyptian Academic Journal of Biological Sciences, 2: 65-74. 
Eltholth, M., Fornace, K., Grace, D., Rushton, J. \& Häsler, B. 2015. Characterization of production, marketing and consumption patterns of farmed tilapia in the Nile Delta of Egypt. Food Policy, 51: 131-143.

Erkan, N. \& Ozden, O. 2008. Quality assessment of whole and gutted sardines (Sardina pilchardus) stored in ice. International Journal of Food Science and Technology, 43: 15491559.

Fathia, G., Shakhtour, M. \& Babji, A. 2013. The effect of powdered cumin sprinkling on biochemical and quality attributes of red tilapia fillets stored in ice. Journal of Food Technology, 11: 14-21.

Food and Agriculture Organization (FAO). 1986. Fish Processing in Africa. FAO fish report 329. FAO Fisheries Department, Rome, Italy.

Food and Agriculture Organization (FAO). 2014. Web-based reporting system for the questionnaire on the implementation of the code of conduct for responsible fisheries. In: FAO Fisheries and Aquaculture Department [online]. Rome. [Cited 12 March 2014].

Fernandez, K., Aspe, E. \& Roeckel, M. 2009. Shelflife extension on fillets of Atlantic salmon Salmo salar using natural additives, super chilling and modified atmosphere packaging. Journal of Food control, 20: 1036-1042.

Galli, A. L., FranzettiR, S., Carelli, L., Piergiovanni, L. \& Fava, P. 1993. Microbiological quality and shelf-life of chilled cod fillets in vacuum-skin and modified atmosphere packaging. Packaging Technology and Science, 6: 147-157.

Gökodlu, N., Özden, Ö. \& Erkan, N. 1998. Physical, chemical and sensory analyses of freshly harvested sardines (Sardina pilchardus) stored at $4^{\circ} \mathrm{C}$. Journal of Aquatic Food Product Technology, 7: 5-15.

Goliat, C., Kapute, F. \& Valeta, J. 2016. Effect of prolonged storage in ice on nutrient composition and sensory quality of whole fresh pond raised tilapia fish (Oreochromis shiranus). American Journal of Food and Nutrition, 4: 127-130.

Gomez, K. A. \& Gomez, A. A. 1984. Statistical Procedures for Agricultural Research (2 ${ }^{\text {nd }}$ ed.). John Wiley and sons, New York.
Goulas, A. E. \& Kontominas, M. G. 2007. Combined effect of light salting modified atmosphere packaging and oregano essential oil on the shelf of sea bream (Sparus aurata). Bio chemistry, 100: 287-296.

Huss, M. L. 1978. Varit Väldigt Nära Döden (Have Been Very Close to the Death) (in Swedish). Gustav and Ester Andersson, Lund.

Huss, H. H. 1988. Fresh fish-quality and quality changes .A training manual prepared for the FAO/DANIDA Training Programme on Fish Technology and Quality Control. Rome, Italy: FAO of the United Nations Danish International Development Agency. Series, 29:15-38

Huss, H. H. 1995. Quality and quality changes in fresh fish. FAO Fisheries Technial Paper No. 348, Food and Agriculture Organization (FAO) of the United Nations, Rome, Italy.

Ibrahim, S. M. \& El- Sherif, S. A. 2008. Effects of some plants extracts on quality aspects of frozen tilapia (Oreochrmis niloticus L.) fillet. Global Veterinaria, 2: 62- 68.

IFST. 1999. Development and Use of Microbiological Criteria in Foods. Institute of Food Science and Technology (UK). London.

ILRI. 2011. CRP 3.7: More Meat, Milk and Fish by and for the Poor: Proposal. Nairobi: International Livestock Research Institute.

International Commission on Microbiological Specifications for Foods (ICMSF). 1986. Sampling plan and recommended microbiological limits for Seafood.

Ishak, M. 1980. The fisheris of the Nile. ICLARM, (Report), 21-25.

Jinadasa, B. K. K. 2014. Determination of quality of marine fishes based on total volatile base nitrogen test (TVB- N). Nature and Science, 12: 106-111.

Khallaf, M. F. 1986. Some Changes That Occur Through Processing and Storage Fish. Ph. D. Thesis, Faculty of Agriculture, Ain Shams University.

Kyrana, V. R., Lougovois, V. P. \& Valsamis, D. S. 1997. Assessment of shelf - life of maricultured gilthead sea bream (Sparus aurata) stored in ice. International Journal of Food Science and Technology, 32: 339 - 347. 
Liu, S., Fan, W., Zhong, S., Ma, C., Li, P., Zhou, K., Peng, Z. \& Zhu, M. 2010. Quality evaluation of tray-packed tilapia fillets stored at $0^{\circ} \mathrm{C}$ based on sensory, microbiological, biochemical and physical attributes. African Journal of Biotechnology, 9: 692-701.

Lopez-Caballero, M. E., Perez-Mateos, M., Montero, P. \& Borderias, A. J. 2000. Oyster preservation by high-pressure treatment. Journal of Food Protection, 63: 196-201.

Malle, P. \& Tao, S. H. 1987. Rapid quantitative determination of trimethylamine using steam distillation. Journal of Food Protection, 50: 756 -760.

MANAGE. 2008. National Institute of Agricultural Extension Management, Processing and Value Addition in Fisheries. Rajendranagar, Hyderabad, Andhra Pradesh, India.

Mazorra-Manzano, M. A., Pacheco-Aguilar, E. I., Diaz-Rojas, E. I. \& Lugo-Sanchez, M. E. 2000. Postmortem changes in black skipjack muscle during storage in ice. Journal of Food Science, 65: 774-779.

Moawad, R. K., Mohamed, G. F., Hanna, A., Bareh, G. F. \& Mahmoud, K. F.2017 . Assessment of hurdle technology to preserve Nile tilapia fillets during refrigeration with the application of marjoram oil/polyphosphates dipping. Asian Journal of Scientific Research, 10: 116-127.

Muhammet, B. \& Sevim, K. 2007. Storage properties of three types of fried whiting balls at refrigerated temperatures. Turkish Journal of Fisheries and Aquatic Sciences, 7: 65-70.

Nunes, M. L., Batista, I. \& Decampos, R. M. 1992. Physical, chemical and sensory analysis of sardine stored in ice. Journal of the Science of Food and Agriculture, 59: 37-43.

Ocaño- Higuera, V. M., Maeda- Martínez, A.N., Marquez- Ríos, E., Canizales- Rodríguez, D. F., Castillo- Yáñez, F. J., Ruiz - Bustos, E., Graciano-Verdugo, A. Z. \& PlascenciaJatomea, M. 2011. Freshness assessment of ray fish stored in ice by biochemical, chemical and physical methods. Food Chemistry, 125: 49-54.

Okeyo, G., Lokuruka, M. N. \& Matofari, J. W. 2009. Nutritional composition and shelf life of the lake Victoria Nile perch (Lates nilotucs) stored in ice. African Journal of Food Agriculture, Nutrition Development, 9: 901 - 919.

Özyurt, G., Kuley, E., Özkütük , S. \& Özogul, F. 2009. Sensory, microbiological and chemical assessment of the freshness of red mullet (Mullus barbatus) and goldband goat fish ( Upeneus moluccensis) during storage in ice. Food Chemistry, 11: 505 - 510.

Pacheco-Aguilar, R., Ocan̆o-Higuera, V. M., Castillo-Yaňez, F. J., Moran-Palacioe, E. F., Marquez-Rios, E. \& Lugo-Sanchez, M. E. 2003. Changes in postmortem quality indices in finescale triggerfish muscle stored in ice. Journal of Food Biochemistry, 27: 333-352.

Ruiz-Capillas, C. \& Moral, A. 2001. Correlation between biochemical and sensory quality indices in hake stored in ice. Food Research International, 34: 441- 447.

Sallam, K. I., Ahmed, A. M., Elgazzar, M. M. \& Eldaly, E. A. 2007. Chemical quality and sensory attributes of marinated pacific saury (Cololabis saira) during vacuum- packaged storage at $4^{\circ} \mathrm{C}$. Food Chemistry, 102: 10611070 .

Salaudeen, M. M., Akande, G. R., Oguntade, O.R., Afolabi, O.O., Olusola, A.O. \& Ezekiel, M.O. 2010. Effect of preservatives on microbial safety and quality of smoked catfish (Clarias gariepinus) during ambient storage. acta SATECH, 3: 81-86.

Silva, T. M., Sabaini, P. S., Evangelista, W. P., Maria, B, A. \& Gloria, M. B .A. 2011. Occurrence of histamine in Brazilian fresh and canned tuna. Food Control, 22: 323-327.

Yasmin, L., Kamal. M., Ahmed. K. M., Azinaddin. M. N. \& Islam, M. N. 2001. Studied on the post mortem changes in genetically improved farmed tilapia (Oreochromis niloticus) during ice storage. Pakistan. Journal of Biological Sciences, 4: 114-1148.

Zang, B. \& Deng, S. 2012. Quality assessment of Scomber japonicas during different temperature storage: Biochemical, textural and volatile flavor properties. International Conference on Artificial Intelligence and Soft Computing Lecture Notes in Information Technology, 12: 301-307. 


\section{تقييم جودة أسماك البلطى النيلى و البورى التى تم جمعها

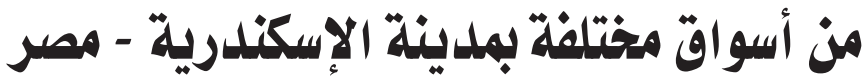

سحدية محمد هاشم محمد ، على أحمد عبد النبى ،محمد خليل محمد خليل،

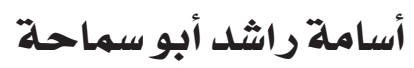

قسم علوم وتقنية الأغذية - كلية الزراعة - الشاطبى - جامعة الأسكندرية - الأسكندرية -

جمهورية مصر العربية

الهدف من هذه الدراسة هو تقييم جودة أسماك البلطى والبورى التى تم جمعها من أسواق مختلفة بمدينة

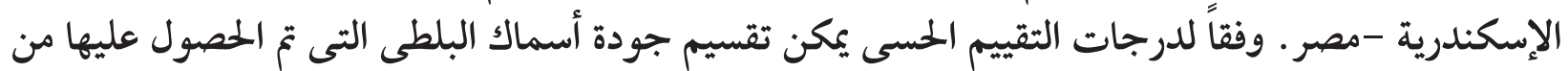

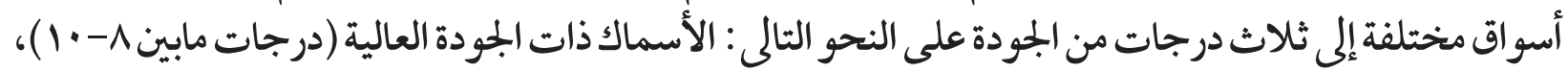

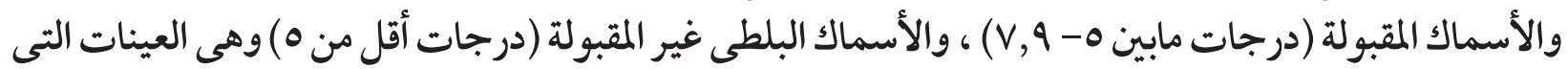
تم الحصول عليها من سوق الهانوفيل. أوضحت النتائج ان كل قيم القواعد النيتروجينية الكلية المتطايرة بالنسبة لكل من البلطى والبورى أقل من الحدود المسموح بها تبعاً للمو اصفات القياسية المصرية. أوضحت النتائج أن كل قيم مر كب ثلاثى ميثيل الأمين بالنسبة لكل من البلطى والبورى كانت أقل من الحدود المسموح بها.

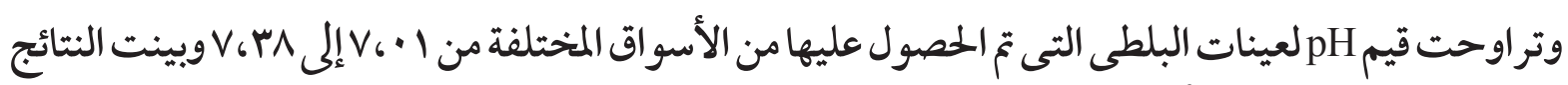

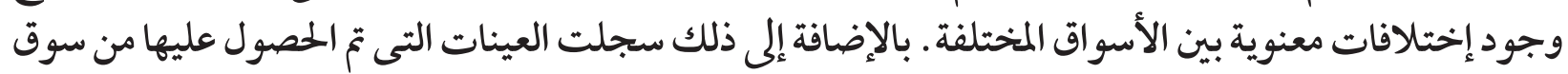

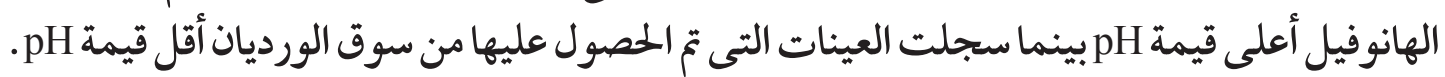

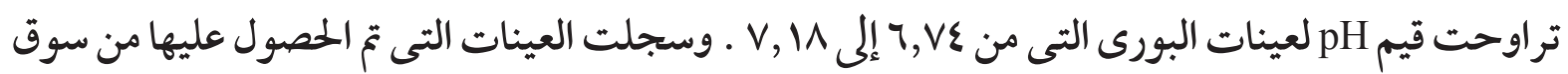

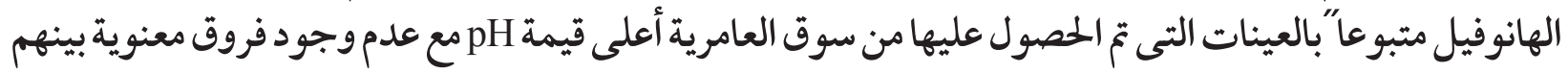

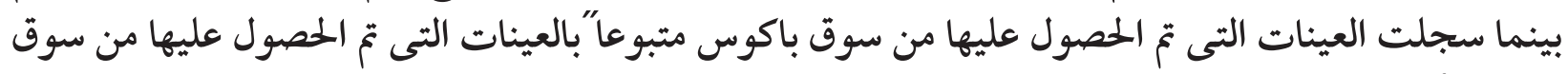

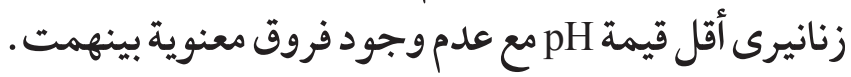
وقد تبين من هذه الدراسة أن عد البكتيريا المحبة للحر ارة المنخفضة لأسماك البلطى والبورى التى تم الحصول

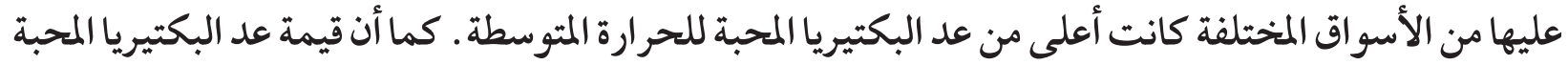
للحرارة المتوسطة و المنخفضة بالنسبة لكل من البلطى والبورى كانت أقل من الحدود الموصى على بهانيا. 